\title{
Pengaruh Laju Aliran Udara Terhadap Efisiensi Penyisihan Organik di dalam Air Lindi dengan Menggunakan Teknik Oksidasi Lanjut $\left(\mathrm{O}_{3} / \mathrm{H}_{2} \mathrm{O}_{2}\right)$
}

\author{
Effect of Air Flow Rate on the Efficiency of Organic Removal in \\ Leachate Using Advanced Oxidation Process $\left(\mathrm{O}_{3} / \mathrm{H}_{2} \mathrm{O}_{2}\right)$
}

\author{
MOHAMAD RANGGA SURURI*, MAYANG AFI FADIYAH, SITI AINUN SALEH, MILA DIRGAWATI \\ Program Studi Teknik Lingkungan, Institut Teknologi Nasional Bandung, JL. PHH Mustofa No.23 Bandung 40124, Telepon : +62 22 \\ 7272215, Fax +62 227202892. \\ Email: rangga@itenas.ac.id
}

\begin{abstract}
Leachate has complex characteristics, and it is commonly processed biologically in the Leachate Treatment Plant (IPL) in Indonesia. However, as the landfill ages, the leachate becomes less biodegradable. An appropriate technique is needed to treat leachate at IPL, and one of the promising methods is advanced oxidation with $\mathrm{O}_{3} / \mathrm{H}_{2} \mathrm{O}_{2}$. This study examined the effect of air flow rate on the concentration of residual ozone (KSO) and its efficiency to remove organic compounds using the $\mathrm{O}_{3} / \mathrm{H}_{2} \mathrm{O}_{2}$ process. Leachate samples were collected as grab samples from TPA Sarimukti Bandung. As much as 1 $L$ of leachate samples were placed in an ozone contactor equipped with a filter disc with a pore size of 100-160 $\mu \mathrm{m}$. The dose of $\mathrm{H}_{2} \mathrm{O}_{2}$ was continuously added to $1.197 \mathrm{~g} / \mathrm{L}$. Compressor was used to provide airflow with variations of 2, 3, and $4 \mathrm{~L} / \mathrm{min}$. Dissolved Oxygen (DO) was measured to determine the concentration of residual ozone (KSO) and validated by examining KSO measurements with the Indigo colorimetric method. A strong relationship between $K S O$ and $D O\left(R^{2}=0.99\right)$ was observed at an airflow rate of $4 \mathrm{~L} / \mathrm{min}$. The highest ozone mass transfer coefficient $\left(K_{L} a,{ }_{0}\right)$ was recorded at a $4 \mathrm{~L} /$ minute flow rate with $0.0022 \mathrm{~min}^{-1}$ at $27^{\circ} \mathrm{C}$. The best removal efficiency has occurred at the fastest air flow rate $(4$ $\mathrm{L} / \mathrm{min}$ ) with $\mathrm{COD}$, and $U \mathrm{~V}_{254}$ removal was $88.89 \%$ and $14.87 \%$, respectively.
\end{abstract}

Keywords: DO, flow variation, $\mathrm{KSO}$, leachate, $\mathrm{O}_{3} / \mathrm{H}_{2} \mathrm{O}_{2}$, organic, mass transfer

\begin{abstract}
ABSTRAK
Karakteristik lindi sangatlah kompleks dan di Indonesia, Instalasi Pengolahan Lindi (IPL) pada umumnya menggunakan sistem pengolahan biologis. Namun demikian, seiring dengan pertambahan umur urugan sampah, lindi semakin tidak biodegradable. Teknik pengolahan tepat diperlukan untuk mengolah lindi di IPL. Salah satu teknik yang sering digunakan adalah oksidasi lanjut dengan $\mathrm{O}_{3} / \mathrm{H}_{2} \mathrm{O}_{2}$ dengan mentransferkan gas ozon ke dalam air lindi yang diukur sebagai Konsentrasi Sisa Ozon (KSO) dan menambahkan $\mathrm{H}_{2} \mathrm{O}_{2}$ untuk meningkatkan pembentukan $\mathrm{OH}^{\bullet}$ di dalam air. Penelitian ini bertujuan untuk mengetahui pengaruh laju aliran udara terhadap KSO serta pengaruhnya terhadap efisiensi penyisihan senyawa organik pada proses $\mathrm{O}_{3} / \mathrm{H}_{2} \mathrm{O}_{2}$. Sampel lindi diambil secara grab sampling dari TPA Sarimukti Bandung. Sebanyak $1 \mathrm{~L}$ sampel ditempatkan pada kontaktor ozon yang dilengkapi filter disc dengan pori

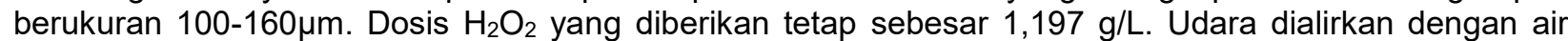
compressor dengan variasi debit udara 2, 3, dan 4 L/menit. Pada penelitian ini, pengukuran Dissolved Oxygen (DO) digunakan sebagai pendekatan untuk mengukur KSO. Validasi dilakukan dengan meneliti hubungan antara KSO dan DO dan pengukuran KSO dilakukan dengan metode indigo colorimetric method. Hasil penelitian menunjukkan KSO dan DO memiliki hubungan yang kuat $\left(R^{2}=0,99\right)$ pada variasi aliran udara $4 \mathrm{~L} /$ menit. Laju aliran udara tercepat terjadi ketika nilai koefisien transfer masa ozon $\left(\mathrm{K}_{\mathrm{L}} \mathrm{a}, \mathrm{O}_{3}\right)$ mencapai nilai tertinggi $\left(0,0022\right.$ menit $\left.^{-1}\right)$ pada suhu $27^{\circ} \mathrm{C}$. Hasil penelitian membuktikan efisiensi penyisihan COD $(88,89 \%)$ dan $U_{254}(14,87 \%)$ tertinggi terjadi pada laju aliran udara tercepat selama 180 menit.
\end{abstract}

Kata kunci: DO, aliran udara $\mathrm{KSO}$, lindi, $\mathrm{O}_{3} / \mathrm{H}_{2} \mathrm{O}_{2}$, organik, transfer masa

\section{PENDAHULUAN}

Teknik pengurugan (landfilling) merupakan teknik yang paling banyak digunakan untuk proses pengolahan akhir sampah kota(1-3), terutama di negara berkembang ${ }^{(4)}$, karena biaya penerapan teknik ini yang dinilai lebih ekonomis $^{(5)}$. Salah satu produk samping pada pengolahan sampah dengan teknik pengurugan (landfill) adalah timbulnya cairan yang disebut lindi ${ }^{(1,2)}$. Cairan ini dihasilkan dari proses dekomposisi materi sampah atau karena 
masuknya air eksternal ke dalam timbunan sampah yang dikenal dengan sebutan lindi(6). Pengolahan lindi di Indonesia pada umumnya dilakukan secara biologi seperti dengan menggunakan kolam stabilisasi atau teknik pengolahan secara anaerobik atau aerobik lainnya. Waktu proses yang dibutuhkan pada teknik ini cukup lama, menyebabkan lahan yang dibutuhkan untuk Instalasi Pengolahan Lindi (IPL) menjadi cukup luas. Selain itu harus diperhatikan bahwa kualitas lindi mengalami perubahan seiring dengan waktu. Semakin tua umur timbulan maka bagian bahan organik yang biodegradable akan lebih kecil dari bagian bahan organik yang non-biodegradable(1).

Kenyataan menunjukkan bahwa semakin lama umur tumpukan sampah pada sel timbunan, maka semakin sulit lindi diolah secara biologi(6). Salah satu alternatif pengolahan yang menarik untuk mengolah lindi adalah proses Advance Oxidation Process (AOP) dengan menggunakan $\mathrm{O}_{3} / \mathrm{H}_{2} \mathrm{O}_{2}{ }^{(7)}$. Pada proses $\mathrm{O}_{3} / \mathrm{H}_{2} \mathrm{O}_{2}$ dekomposisi ozon dipercepat menjadi $\mathrm{OH}^{\bullet}$ (radikal $\mathrm{OH}$ ), entity dengan potensi oksidasi yang paling besar dalam air sehingga dapat mengoksidasi senyawa organik kompleks pada air lindi yang sukar didegradasi secara biologi $(7,8)$. Selain itu penggunaan Teknik AOP berbasiskan ozon dapat meningkatkan biodegradibilitas lindi melalui kenaikan rasio $\mathrm{BOD} / \mathrm{COD}^{(9,10)}$, sehingga lindi tersebut siap diolah secara biologi.

Lindi dari TPA di Indonesia tentu memiliki ciri khas dibandingkan lindi dari TPA di luar negeri, ciri khas lindi sampah Indonesia memiliki karakter $\mathrm{pH}$ tidak asam ${ }^{(2)}$. Selain itu, salah satu kekurangan teknik $\mathrm{O}_{3} / \mathrm{H}_{2} \mathrm{O}_{2}$ adalah adanya kebutuhan $\mathrm{H}_{2} \mathrm{O}_{2}$ yang dapat membebani biaya pengolahan. Peneliti terdahulu telah menunjukkan bahwa penambahan $\mathrm{H}_{2} \mathrm{O}_{2}$ secara terus menerus tidak akan meningkatkan efisiensi penyisihan proses $\mathrm{O}_{3} / \mathrm{H}_{2} \mathrm{O}_{2}{ }^{(10)}$. Sehingga salah satu cara yang dapat dilakukan untuk menghemat biaya operasional aplikasi teknik $\mathrm{O}_{3} / \mathrm{H}_{2} \mathrm{O}_{2}$ adalah dengan memberikan aliran udara yang dapat maksimal melarutkan ozon dan $\mathrm{OH}^{\bullet}$ (radikal $\mathrm{OH}$ ). Sehingga sebelum teknik $\mathrm{O}_{3} / \mathrm{H}_{2} \mathrm{O}_{2}$ diterapkan, seyogyanya pengaruh aliran udara terhadap koefisien kelarutan ozon (KLa,o3) dalam lindi dipahami. Namun pengukuran konsentrasi sisa ozon tidaklah mudah dan murah sehingga untuk kepentingan praktis beberapa peneliti menghubungkannya dengan kelarutan oksigen. Penelitian ini akan mengevaluasi pengaruh kecepatan udara dan hubungannya dengan kelarutan udara dan kelarutan oksigen. Penelitian ini juga mengamati pengaruh laju udara pada teknik $\mathrm{O}_{3} / \mathrm{H}_{2} \mathrm{O}_{2}$ terhadap penyisihan COD dan $\mathrm{UV}_{254}$ yang merupakan parameter kunci pada proses pengolahan lindi. Hasil dari penelitian ini dapat menjadi masukan penerapan Teknik $\mathrm{O}_{3} / \mathrm{H}_{2} \mathrm{O}_{2}$ sehingga bisa lebih efektif dari sisi teknis dan ekonomis ketika diaplikasikan.

\section{BAHAN DAN METODE}

\section{1 Lokasi Penelitian dan Pengambilan Sampel}

Sampel yang digunakan pada penelitian ini adalah lindi yang berasal dari Tempat Pemrosesan Akhir (TPA) Sarimukti yang terletak di Desa Sarimukti, Kecamatan Cipatat, Kabupaten Bandung Barat. TPA Sarimukti beroperasi sejak Mei 2006 dan dikelola oleh Pemerintah Provinsi Jawa Barat. Saat ini, TPA ini telah beroperasi lebih dari 12 tahun (termasuk TPA tua) dan dioperasikan secara controlled landfill. Pada tahun 2019 TPA ini menampung 698.906.690 ton sampah dari Kota Bandung, Kabupaten Bandung, Kota Cimahi dan Kabupaten Bandung Barat(11). Pengambilan sampel dilakukan secara grab sampling. Titik pengambilan sampel merupakan inlet dari IPL TPA Sarimukti dan sampel lindi diambil sebanyak $20 \mathrm{~L}$ dalam satu kali pengambilan.

\section{2 Alat, Bahan dan Rancangan Penelitian}

Skema rangkaian alat yang digunakan pada penelitian ini antara lain air compressor, flow meter, generator ozon dengan tabung corona stainless dengan daya 120 watt, dan kontaktor yang dapat dilihat pada Gambar 1. Air compressor mengalirkan udara yang kemudian dialirkan menuju flow meter sebagai pengatur debit udara. Variasi debit udara pada penelitian ini sebesar 2, 3, dan $4 \mathrm{~L} /$ menit, sementara pengaruh debit udara hanya akan ditinjau terhadap Konsentrasi Sisa Ozon (KSO) terlarut pada lindi (dapat dilihat pada bagian 2.5). Setelah melewati flow meter, udara masuk ke ozon generator di mana oksigen dalam udara yang masuk akan dikonversikan menjadi ozon. Gas Ozon sebesar $3 \mathrm{gr} / \mathrm{jam}$ yang dihasilkan dari generator kemudian dialirkan ke kontaktor melalui

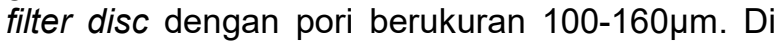
dalam kontaktor, lindi sebanyak 1 liter ditempatkan dengan penambahan $\mathrm{H}_{2} \mathrm{O}_{2}$ yang konstan sebesar 1,197 $\mathrm{g} / \mathrm{L}$ pada setiap variasi. Konsentrasi $\mathrm{H}_{2} \mathrm{O}_{2}$ yang diberikan sebesar 1,197 $\mathrm{g} / \mathrm{L}$ karena pada penelitian sebelumnya memberikan hasil penyisihan terbaik pada Teknik $\mathrm{O}_{3} / \mathrm{H}_{2} \mathrm{O}_{2}$ dengan sampel dari TPA Sarimukti ${ }^{(12)}$. Pengukuran KSO serta pengujian efektifitas proses ozonisasi dan AOP dilakukan pada waktu kontak 180 menit dengan interval waktu pengambilan sampel per 30 menit. 


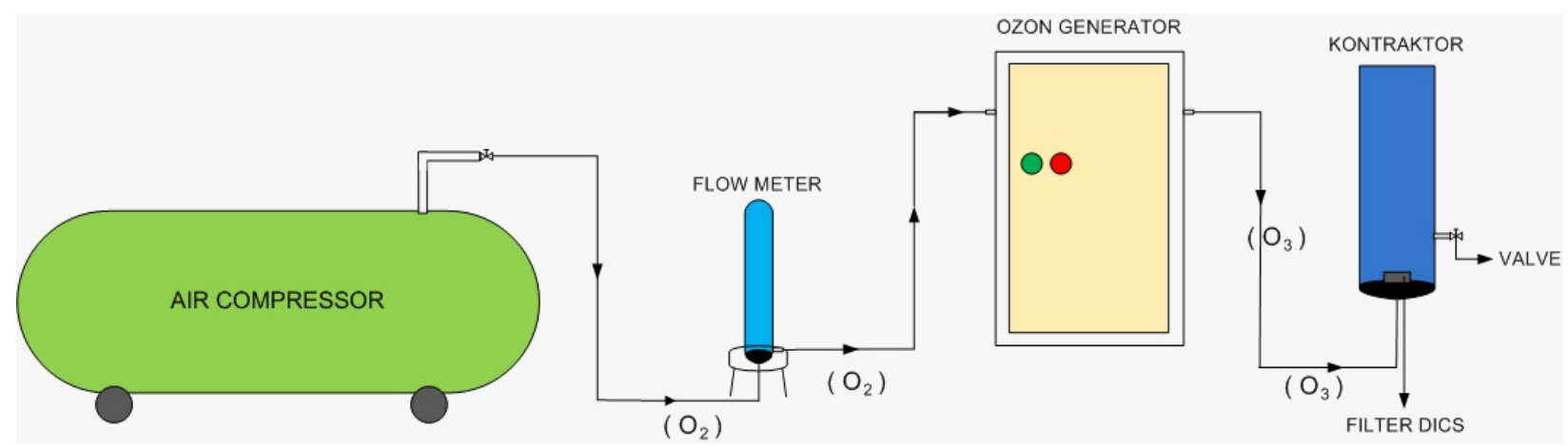

Gambar 1. Skema rangkaian alat yang digunakan pada proses $A O P\left(\mathrm{O}_{3} / \mathrm{H}_{2} \mathrm{O}_{2}\right)$

\section{3 Pemeriksaan Karakteristik Lindi}

Parameter yang diukur pada sampel lindi sebelum diolah adalah parameter $\mathrm{pH}$, alkalinitas (karbonat dan bikarbonat), COD, dan $\mathrm{UV}_{254}$. Pengukuran sampel lindi terolah dilakukan pada seluruh parameter kecuali alkalinitas. $\mathrm{pH}$ diukur berdasarkan SNI 06-6989-11-2004. Alkalinitas diukur sebagai karbonat dan bikarbonat menggunakan metode potensiometri menurut SNI 06-2422-1991. Parameter organik diwakili oleh COD dan $\mathrm{UV}_{254}$. COD diukur menggunakan metode refluks tertutup berdasarkan Standard Methods 5220-C(13) dan $\cup_{254}$ diukur berdasarkan Standard Methods 5910.

\section{4 Perhitungan Nilai Koefisien Transfer Masa Ozon (K,a,o3)}

Pengukuran ozon terlarut di dalam air diukur sebagai $\mathrm{KSO}^{(14)}$ karena ozon sangat cepat terdekomposisi di dalam air ${ }^{(8)}$. Perhitungan $\mathrm{K} \mathrm{L}$, Оз dilakukan secara tidak langsung melalui pengukuran $\mathrm{DO}$, hal ini dilakukan karena proses pengukuran KSO yang mahal. Data DO diukur pada setiap variasi debit udara dan diolah menggunakan rumus pada persamaan di bawah $^{(15)}$ :

$\ln \left(C_{s}-C_{t}\right)=\ln \left(C_{s}-C_{o}\right)-K_{L}$ a.t

Keterangan :

$\mathrm{K}_{\mathrm{La}}=$ Koefisien transfer total

$\mathrm{C}_{0}=$ konsentrasi awal oksigen $(\mathrm{mg} / \mathrm{L})$

$C_{t}=$ konsentrasi oksigen pada waktu kontak setiap variasi $(\mathrm{mg} / \mathrm{L})$

$\mathrm{C}_{\mathrm{s}}=$ konsentrasi jenuh oksigen $(\mathrm{mg} / \mathrm{L})$

Persamaan 1 di atas kemudian dilinearkan untuk mendapatkan nilai $\mathrm{K} \mathrm{L} a, \mathrm{O}_{2}$. Nilai koefisien tersebut kemudian dikonversi menjadi nilai $\mathrm{K}\left\llcorner\mathrm{a}, \mathrm{O}_{3}\right.$, melalui persamaan(16).

$\mathrm{K} L \mathrm{a}, \mathrm{O}_{3}=0,622 . \mathrm{K} \mathrm{La} \mathrm{O}$

Persamaan 2 valid pada suhu $20{ }^{\circ} \mathrm{C}$ sehingga dibutuhkan persamaan yang dapat mengubah perhitungan berdasarkan temperatur yang diinginkan. Persamaan yang dapat mengubah sesuai temperatur $20^{\circ} \mathrm{C}$ dapat dilihat pada persamaan $3^{(16)}$.
$K_{L a, t}=\frac{K_{L a 20}}{\theta^{20-t}}$

Keterangan :

$\mathrm{K}\left\llcorner\mathrm{a}, \mathrm{t}=\mathrm{K} \mathrm{La}\right.$ pada temperatur suhu tertentu $\left({ }^{\circ} \mathrm{C}\right)$

$\mathrm{K}_{\mathrm{La}}{ }_{20}=\mathrm{K}_{\mathrm{L}}$ p pada suhu $20^{\circ} \mathrm{C}$

$\theta=$ faktor koreksi temperatur yang bernilai 1,024

$\mathrm{t}=$ suhu yang dikondisikan

\section{5 Validasi Pengukuran}

Hasil pengukuran KSO berdasarkan teknik pengukuran $\mathrm{O}_{2}$ kemudian divalidasi melalui pengukuran KSO pada menit ke 120, 150, dan 180. Pengukuran KSO dilakukan pada menit tersebut setelah kekeruhan dari ozon menurun sehingga tidak menganggu pemeriksaan KSO yang menggunakan spektrofotometer. Hasil pengukuran KSO akan dihubungkan dengan hasil pengukuran DO melalui regresi linier. Pengukuran KSO berdasarkan standard methods $4500-\mathrm{O}_{3}$ (indigo colorimetric). Perhitungan konsentrasi sisa ozon dapat dilihat pada persamaan berikut ini ${ }^{(13)}$ :

$$
m g O_{3} / L=\frac{100 \times \Delta A}{f \times b \times V}
$$

Keterangan :

$\Delta \mathrm{A}=$ selisih absorban antara sampel dan blanko

$\mathrm{b}=$ panjang kuvet yang digunakan $(\mathrm{cm})$

$\mathrm{V}=$ volume sampel $(\mathrm{ml})$

$f=0,42$

Pada penelitian ini diperlukan identifikasi hubungan besaran nilai $\mathrm{K}_{\mathrm{L} a} \mathrm{O}_{3}$ dengan $\mathrm{KSO}$. Hal tersebut dapat ditentukan dengan menentukan regresi linier hubungan antara DO dengan KSO.

\section{HASIL DAN PEMBAHASAN}

\section{1 Karakteristik Awal Lindi TPA Sarimukti}

Seperti terlihat pada Tabel 1, suhu lindi berkisar antara $25-29{ }^{\circ} \mathrm{C}$, sementara $\mathrm{pH}$ awal pada lindi cenderung basa $(8,6-8,7)$. Hasil ini menunjukkan bahwa kekhasan lindi sampah Indonesia memiliki karakter $\mathrm{pH}$ yang tidak asam $^{(2)}$. Nilai $\mathrm{pH}$ yang cenderung basa membantu proses oksidasi lanjut karena dapat mempercepat proses dekomposisi ozon ${ }^{(8)}$. 
Nilai karbonat dan bikarbonat menunjukkan kapasitas buffer sampel untuk mempertahankan $\mathrm{pH}$. Karbonat dan bikarbonat bereaksi dengan $\mathrm{OH}^{\bullet}$ (radikal $\mathrm{OH}$ ) atau akan bertindak sebagai chain carriers pada reaksi radikal yang beruntun $^{(17)}$, namun demikian beberapa peneliti lain ${ }^{(8,18)}$ menyatakan keduanya merupakan inhibitor reaksi berantai pada air limbah. Tabel 1 memperlihatkan nilai karbonat dan bikarbonat sampel secara berurutan berada pada rentang 2460-2800 $\mathrm{mg} / \mathrm{L}$ dan 732-1037 mg/L. Kandungan senyawa organik diwakili oleh COD dan $U_{254}$. COD mengukur senyawa organic yang dapat didegradasi secara kimia(19), sementara $U_{254}$ mengukur secara semi kuantitatif senyawa humus dan aromatik dalam air(13,20). Hubungan antara COD dengan $\mathrm{UV}_{254}$ diteliti dan hubungan antara keduanya tidak selalu kuat ${ }^{(21)}$. Konsentrasi sampel COD sebesar $7.920 \mathrm{mg} / \mathrm{L}$, sementara $\mathrm{UV}_{254}$ menunjukkan nilai antara 33,675-37,625 Abs.

Tabel 1. Karakteristik awal lindi

\begin{tabular}{cccc}
\hline No. & Parameter & Satuan & Nilai \\
\hline 1. & $\mathrm{Suhu}$ & ${ }^{\circ} \mathrm{C}$ & $25-29$ \\
\hline 2. & $\mathrm{pH}$ & - & $8,6-8,7$ \\
\hline 3. & Alkalinitas & & \\
& Karbonat $\left(\mathrm{CO}_{3}{ }^{2-}\right)$ & $\mathrm{mg} / \mathrm{L}$ & $2460-2800$ \\
& Bikarbonat $\left(\mathrm{HCO}_{3}{ }^{-}\right)$ & $\mathrm{mg} / \mathrm{L}$ & $732-1037$ \\
\hline 4. & $\mathrm{COD}$ & $\mathrm{mg} / \mathrm{L}$ & 7920 \\
\hline 5. & $\mathrm{UV}_{254}$ & $\mathrm{Abs}$ & $33,675-37,625$ \\
\hline Sumber : Hasil pengukuran, 2015.
\end{tabular}

\section{2 Pengukuran Koefisien Transfer Masa Oksigen ( $\left.\mathrm{K}_{\mathrm{L}} \mathrm{a}, \mathrm{O}_{2}\right)$ dan Ozon $\left(\mathrm{K}_{\mathrm{L}} \mathrm{a}, \mathrm{O}_{3}\right)$}

Proses penelitian didahului dengan perhitungan $\mathrm{K}$ La,O2 melalui pengukuran DO. Tabel 2 menginformasikan data konsentrasi DO di setiap variasi debit udara yaitu $2 \mathrm{~L} /$ menit, 3 L/menit, dan 4 L/menit.

Seperti ditunjukkan Tabel 2, secara umum konsentrasi DO pada seluruh variasi debit udara mengalami kenaikan di setiap waktu kontaknya. Akan tetapi, terdapat perbedaan kandungan oksigen yang cukup signifikan antara variasi 2 dan $3 \mathrm{~L} /$ menit terhadap aliran $4 \mathrm{~L} /$ menit, di mana konsentrasi DO tertinggi pada setiap waktu kontak terjadi pada debit udara $4 \mathrm{~L} /$ menit (Tabel 2). Semakin tinggi debit udara maka konsentrasi DO yang dihasilkan semakin tinggi. Pengendalian transfer massa ozon adalah tahanan film-gas ${ }^{(22)}$, sehingga peningkatan aliran udara menyebabkan turbulensi akan semakin meningkat.

Gambar 2 menunjukkan bahwa nilai $\mathrm{K} \mathrm{La}, \mathrm{O} 2$ pada aliran $4 \mathrm{~L} /$ menit paling tinggi yaitu 0,003 menit $^{-1}$, sementara pada $3 \mathrm{~L} /$ menit sebesar 0,002 menit $^{-1}$ dan pada $2 \mathrm{~L} /$ menit sedikit di bawahnya yaitu 0,001 menit $^{-1}$. Pada variasi kecepatan udara tercepat (4 L/menit), turbulensi lebih meningkatkan nilai koefisien perpindahan gas $\left(\mathrm{K}_{\mathrm{L}} \mathrm{a}\right)^{(23)}$, akibatnya semakin besar kecepatan udara, maka derajat tahanan liquid film menurun dan laju perpindahan gas ozon dari fase cair ke gas meningkat ${ }^{(22)}$. Gambar 2 juga menunjukkan semakin tinggi laju aliran udara akan memperkuat hubungan antara waktu kontak dengan konsentrasi oksigen terlarut di dalam sampel, hal ini terlihat dari nilai $\mathrm{R}^{2}$ yang semakin mendekati 1 pada variasi aliran 4 L/menit.

Nilai KLa,o2 tersebut dikonversi menjadi nilai KLa, о3 menggunakan persamaan 3 (Tabel 3). Bahkan temperatur lindi diperhitungkan dengan menggunakan Persamaan 4, hasil perhitungan tersebut dapat dilihat pada Tabel 3 . Sepertihalnya pada laju oksigen, semakin tinggi debit udara maka nilai $\mathrm{K}_{\mathrm{L} a, 03} 20{ }^{\circ} \mathrm{C}$ dan $\mathrm{K}_{\mathrm{L} a ~ \mathrm{O}_{3}}$ $27{ }^{\circ} \mathrm{C}$ semakin tinggi. Nilai $\mathrm{K}_{\mathrm{L}} \mathrm{a}$, о3 pada suhu 27 ${ }^{\circ} \mathrm{C}$ terendah terdapat pada debit $2 \mathrm{~L} /$ menit yaitu sebesar 0,0007 menit $^{-1}$. Nilai $\mathrm{K}_{\mathrm{L}} \mathrm{a}, 0327^{\circ} \mathrm{C}$ yang tertinggi terdapat pada debit $4 \mathrm{~L} /$ menit yaitu sebesar 0,0022 menit $^{-1}$. Fenomena ini menguatkan pendapat peneliti terdahulu yang menyatakan semakin besar debit oksigen maka kelarutan ozon akan semakin tinggi(24). Namun demikian, hasil perhitungan $\mathrm{K}_{\mathrm{L}}$ a pada $4 \mathrm{~L} /$ menit lebih kecil dari penelitian sebelumnya dengan nilai 0,148 menit $^{-1}$, hal ini terjadi karena proses penelitian terdahulu menggunakan peralatan seperti air stone dan magnetic stirer yang mampu menghasilkan micro bubble(24) sedangkan pada penelitian ini hanya menggunakan udara bebas yang disebarkan dengan filter disc tanpa menggunakan alat pendukung lainnya.

Tabel 2. Konsentrasi DO

\begin{tabular}{|c|c|c|c|c|c|c|c|c|}
\hline \multirow{2}{*}{ Variasi Debit Udara } & \multirow{2}{*}{ Suhu $\left({ }^{\circ} \mathrm{C}\right)$} & \multicolumn{7}{|c|}{ Konsentrasi DO (mg/L) dan Waktu (menit) } \\
\hline & & 0 & 30 & 60 & 90 & 120 & 150 & 180 \\
\hline 2 L/menit & $27^{\circ} \mathrm{C}$ & 3,6 & 4,3 & 4,7 & 4,8 & 4,9 & 5,1 & 5,2 \\
\hline $3 \mathrm{~L} /$ menit & $27^{\circ} \mathrm{C}$ & 4,2 & 5,3 & 5,4 & 5,7 & 5,9 & 6 & 6,3 \\
\hline 4 L/menit & $27^{\circ} \mathrm{C}$ & 4,2 & 6,4 & 6,5 & 6,6 & 6,9 & 7,2 & 7,6 \\
\hline
\end{tabular}

Sumber: Hasil Pengukuran, 2015. 




Gambar 2. Linierisasi nilai $\mathrm{K}_{\mathrm{La} \mathrm{O}} \mathrm{O}_{2}$

Tabel 3. Data hasil perhitungan $\mathrm{K}_{\mathrm{L}}$ a pada setiap variasi debit udara

\begin{tabular}{|c|c|c|c|c|}
\hline Variasi Debit Udara & Persamaan & $\mathrm{K}_{\mathrm{La} \mathrm{O}}$ & $\mathrm{K} \mathrm{La} \mathrm{O}_{3} 20^{\circ} \mathrm{C}$ & $\mathrm{K} \mathrm{La} \mathrm{O} \mathrm{O}_{3} 27^{\circ} \mathrm{C}$ \\
\hline $2 \mathrm{~L} / \mathrm{menit}$ & $y=0,001 x+0,053$ & 0,001 & 0,0006 & 0,0007 \\
\hline $3 \mathrm{~L} /$ menit & $y=0,002 x+0,077$ & 0,002 & 0,0012 & 0,0015 \\
\hline $4 \mathrm{~L} /$ menit & $y=0,003 x+0,078$ & 0,003 & 0,0019 & 0,0022 \\
\hline
\end{tabular}

Sumber : Hasil Perhitungan, 2015.

\section{3 Validasi Hasil Pengukuran Oksigen Terhadap KSO}

Gambar 3(a) memperlihatkan hasil pengukuran KSO dengan tren yang sama dengan hasil pengukuran DO. Pada seluruh variasi debit udara KSO mengalami kenaikan pada setiap waktu kontaknya dan tercatat KSO tertinggi pada variasi $4 \mathrm{~L} /$ menit. Hubungan antara hasil pemeriksaan KSO dan DO ditunjukkan oleh Gambar 3 (b) - (d). Hasilnya menunjukkan hubungan yang kuat antara KSO dan $\mathrm{DO}$ dengan nilai $\mathrm{R}^{2}$ melebihi 0,95 , dan tercatat hubungan antara keduanya meningkat seiring dengan penambahan laju udara. Hubungan DO dengan KSO paling kuat tercatat pada variasi laju udara $4 \mathrm{~L} /$ menit dengan nilai $R^{2}$ mencapai 0,99. Fakta ini memperkuat pernyataan yang menyatakan $1 \mathrm{~mol} \mathrm{O}_{3}$ akan menghasilkan $1 \mathrm{~mol}_{2}$ seperti ditunjukkan persamaan $5^{(25)}$ :

$\mathrm{OH}^{\bullet}+\mathrm{O}_{3} \rightarrow \mathrm{HO}_{2}^{\bullet}+\mathrm{O}_{2} \rightarrow \mathrm{HO}_{4}$

\section{4 Pengaruh Variasi Debit Udara Pada $\mathrm{O}_{3} / \mathrm{H}_{2} \mathrm{O}_{2}$ Terhadap Penyisihan Senyawa Organik}

Bahan organik sangat heterogen dan bisa

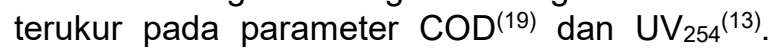
COD mengukur bahan organik yang labil, dapat teroksidasi secara kimia oleh oksidator kuat (bikromat) $^{(19)}$, sementara $U_{254}$ menunjukkan humus dan senyawa aromatik(13), bahkan dapat menunjukkan bahan refractory organic substances dalam air(26). Efisiensi penyisihan COD dan UV 254 pada setiap waktu kontak dapat dilihat pada Gambar 4 dan 5 secara berurutan. Penyisihan parameter organik menunjukkan trend yang serupa yaitu: (i) efisiensi penyisihan parameter organik tersebut mengalami kenaikan seiring penambahan waktu kontak; dan (ii) kenaikan debit udara menyebabkan adanya kenaikan efisiensi penyisihan senyawa organik. Fakta ini memperkuat hasil penelitian terdahulu yang menunjukkan bahwa proses ozonisasi saja dan AOP dapat menurunkan kadar COD sehingga rasio $\mathrm{BOD} / \mathrm{COD}$ dapat meningkat, sehingga kualitas lindi lebih baik dan siap diolah pada proses selanjutnya ${ }^{(9)}$.

Pada Gambar 4 dan 5 di bawah terlihat efisiensi penyisihan tertinggi dicapai pada variasi debit $4 \mathrm{~L}$ /menit dengan penyisihan senyawa organik di menit ke-180 mencapai 90\% untuk COD dan $14,87 \%$ untuk penyisihan $U_{254}$. Jika dibandingkan dengan penelitian sebelumnya dengan sampel dari TPA yang sama serta menggunakan proses $\mathrm{O}_{3} / \mathrm{H}_{2} \mathrm{O}_{2}$ (laju udara 3 L/menit) namun ditambahkan katalis berupa zeolite, tercatat angka penyisihan penyisihan 
COD tidak berbeda jauh dengan hasil penelitian ini(27), namun penyisihan $\mathrm{UV}_{254}$ pada penelitian terdahulu tersebut tercatat dua kali lebih baik $(28,68 \%)$ dibandingkan penelitian ini(27). Hasil ini juga menunjukkan aromatik organik yang terkandung pada lindi lebih sukar disisihkan pada proses $\mathrm{O}_{3} / \mathrm{H}_{2} \mathrm{O}_{2}$ dibandingkan senyawa organik yang labil dan terukur sebagai COD. Selain itu lebih baiknya penyisihan $U_{254}$ pada

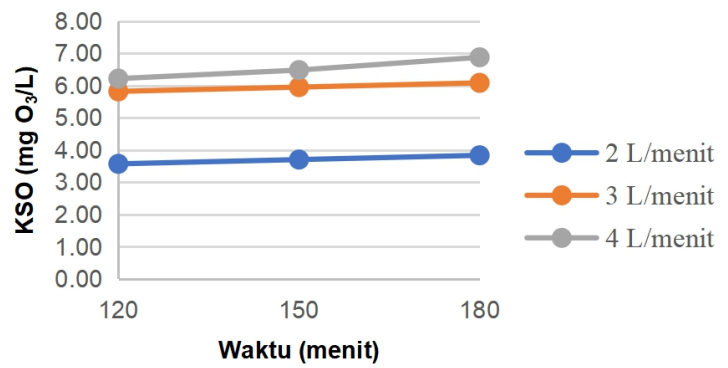

(a)

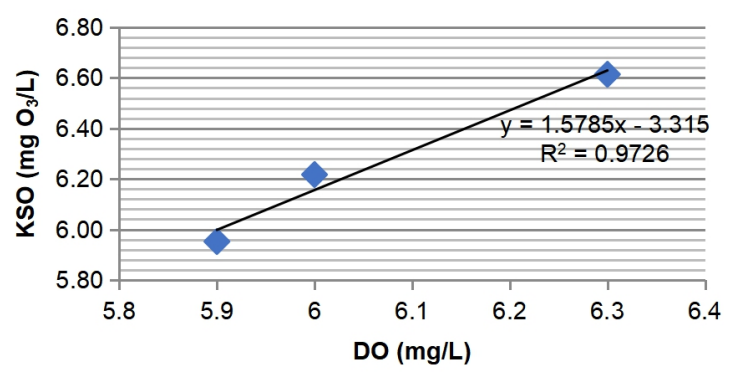

(c) proses yang menggunakan katalis dikarenakan katalis yang digunakan juga dapat berfungsi sebagai adsorben. Lebih lanjut rendahnya efisiensi penurunan $U V_{254}$ menunjukkan organik aromatik yang ada dapat merupakan materi yang sulit terdegradasi oleh ozon yang selektif, sehingga masih banyak materi organik aromatik yang terakumulasi tidak dapat disisihkan secara sempurna oleh teknik $\mathrm{O}_{3} / \mathrm{H}_{2} \mathrm{O}_{2}{ }^{(28)}$.

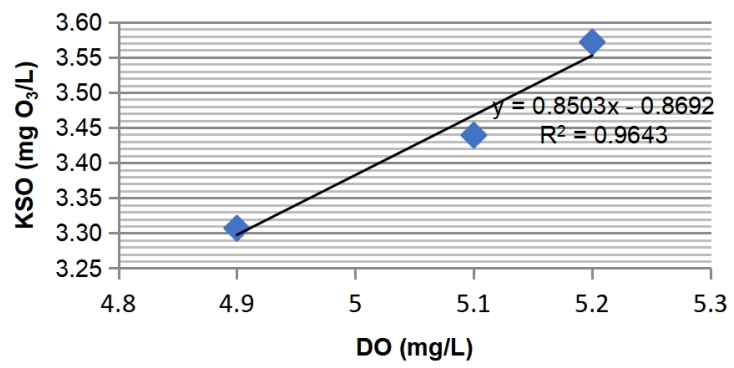

(b)

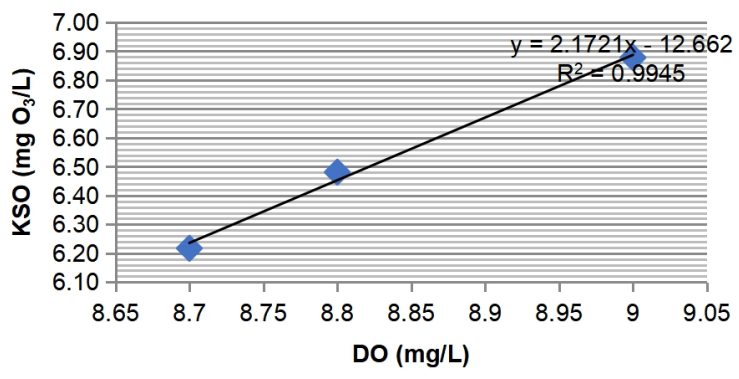

(d)

Gambar 3. (a) Hasil pengukuran KSO dan hubungan antara DO dan KSO pada: (b) 2 L/menit ; (c) 3 L/menit; dan (d) 4 L/menit

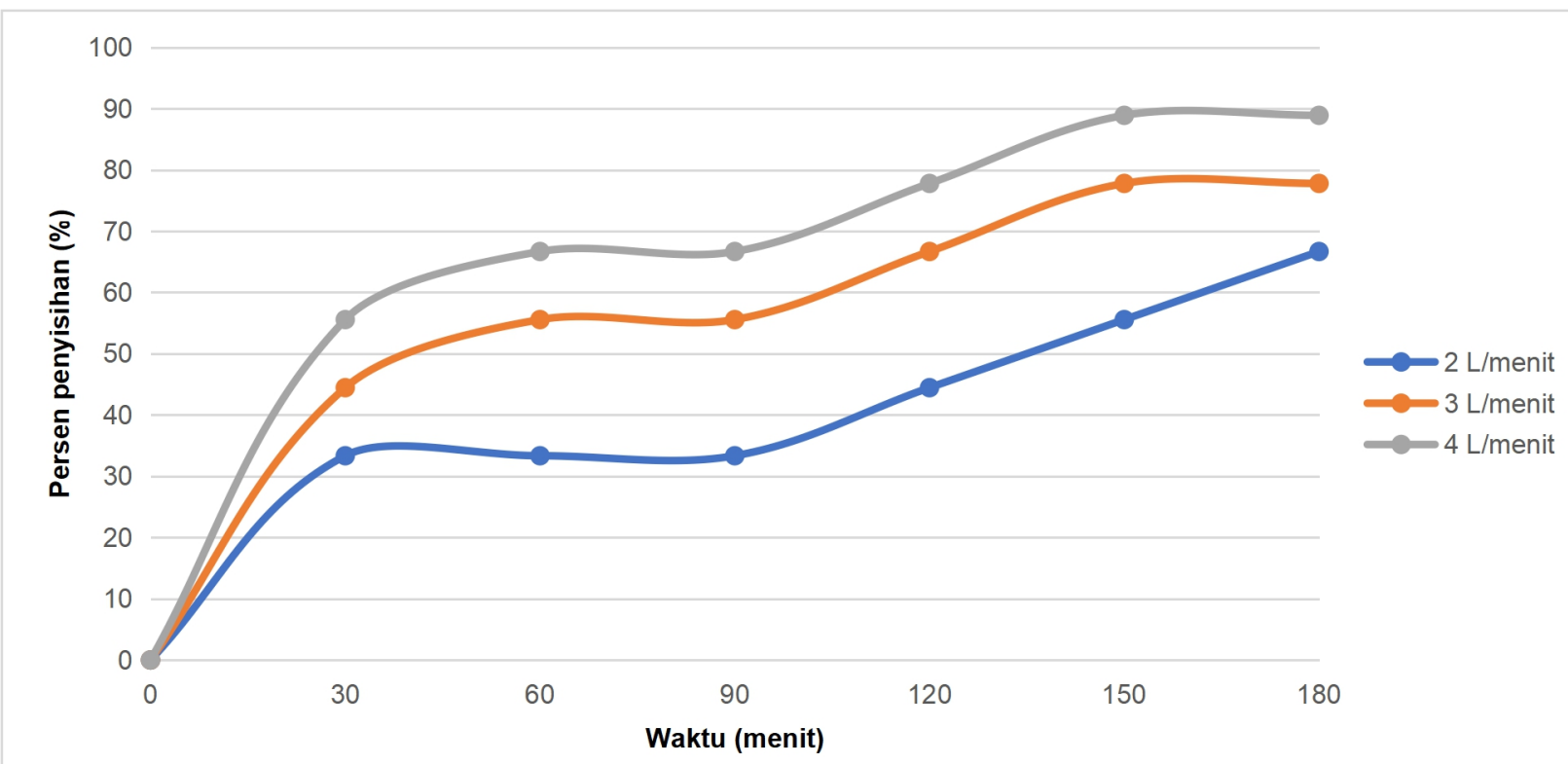

Gambar 4. Efisiensi penyisihan parameter COD selama proses AOP $\left(\mathrm{O}_{3} / \mathrm{H}_{2} \mathrm{O}_{2}\right)$ pada setiap variasi debit udara 


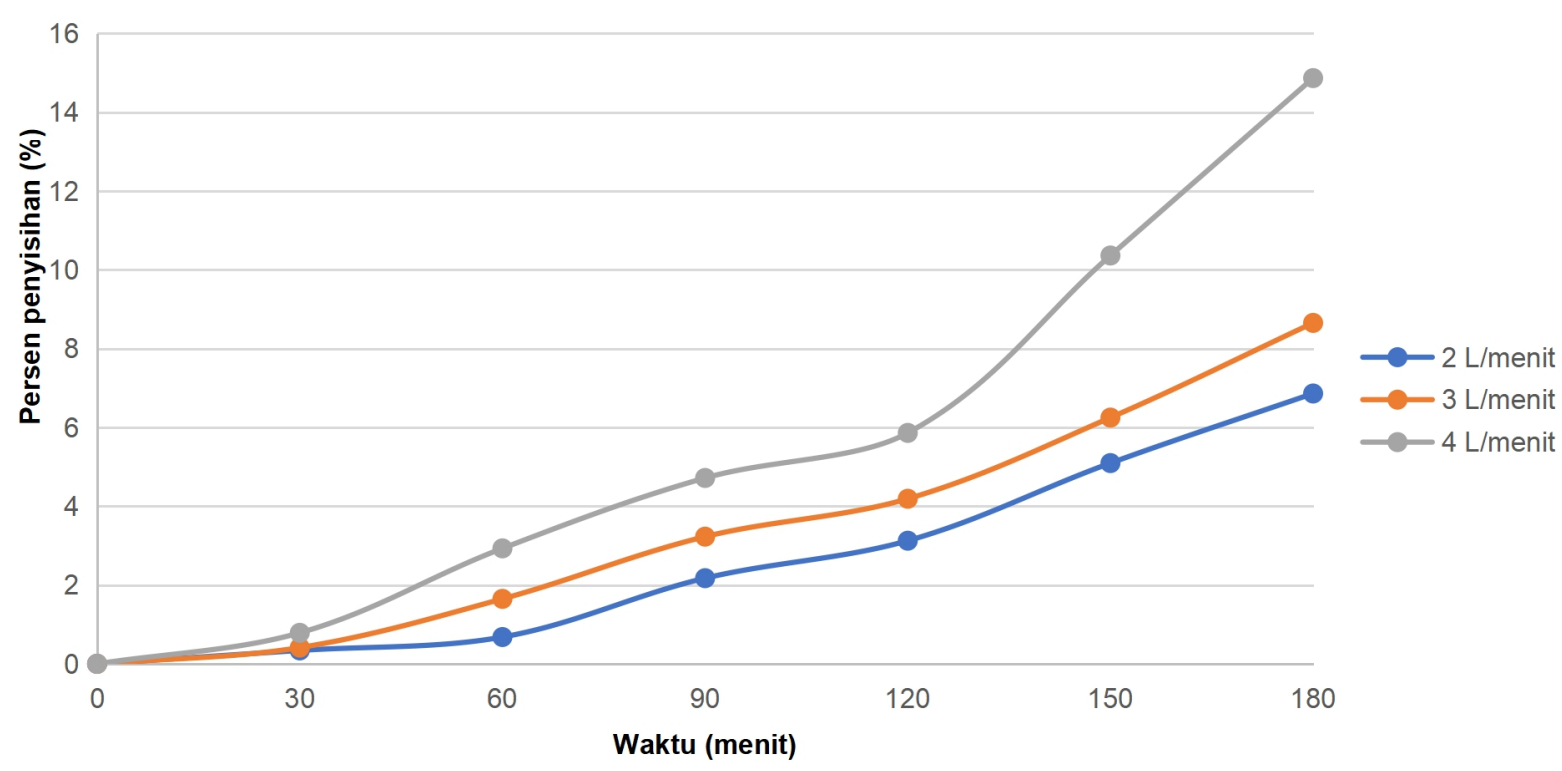

Gambar 5. Efisiensi penyisihan parameter $\mathrm{UV}_{254}$ selama proses $A O P\left(\mathrm{O}_{3} / \mathrm{H}_{2} \mathrm{O}_{2}\right)$ pada setiap variasi debit udara

Tabel 4. pH sampel lindi pada setiap variasi debit dan waktu kontak

\begin{tabular}{cccccccc}
\hline \multirow{2}{*}{ No } & Variasi debit & \multicolumn{5}{c}{ Waktu Kontak } \\
& & $\mathbf{3 0}$ & $\mathbf{6 0}$ & $\mathbf{9 0}$ & $\mathbf{1 2 0}$ & $\mathbf{1 5 0}$ & $\mathbf{1 8 0}$ \\
\hline 1 & 2 L/menit & 8,52 & 8,55 & 8,56 & 8,56 & 8,56 & 8,58 \\
2 & 3 L/menit & 8,53 & 8,64 & 8,82 & 8,99 & 9,11 & 9,21 \\
3 & 4 L/menit & 9,05 & 9,21 & 9,30 & 9,40 & 9,44 & 9,46 \\
\hline
\end{tabular}

Pada penelitian ini, lebih efektifnya penyisihan senyawa organik pada variasi 4 L/menit karena nilai konsentrasi sisa ozon (KSO) dan kelarutan ozon (K⿺a,03) pada debit udara 4 $\mathrm{L} /$ menit tercatat paling tinggi dibandingkan dengan variasi debit udara lainnya (Tabel 2). Selain itu seperti terlihat pada Tabel 4, jika dibandingkan variasi lainnya, pada variasi kecepatan $4 \mathrm{~L} /$ menit $\mathrm{pH}$ tercatat lebih basa dan $\mathrm{pH}$ yang basa akan meningkatkan efisiensi proses pengolahan ${ }^{(6)}$, hal ini disebabkan keberadaan oksidator yang ada terdiri dari ozon dan produk dekomposisinya yaitu $\mathrm{OH}^{\bullet(29)}$. Kondisi ini menggambarkan lebih simulatannya reaksi antara ozon dan $\mathrm{OH}^{\bullet}$ dalam sampel lindi pada variasi $4 \mathrm{~L} /$ menit sehingga proses oksidasi senyawa organik dapat terjadi lebih baik. Persamaan reaksi yang dapat menggambarkan kondisi tersebut adalah ${ }^{(8)}$ :

$\mathrm{O}_{3}+\mathrm{OH}^{-} \rightarrow \mathrm{HO}_{2}^{-}+\mathrm{O}_{2}$

$\mathrm{O}_{3}+\mathrm{HO}_{2}^{-} \rightarrow \mathrm{OH}^{\bullet}+\mathrm{O}_{2} \cdot-\mathrm{O}_{2}$

$\mathrm{OH}^{\bullet}+\mathrm{RH} \rightarrow \mathrm{RH} \cdot+\mathrm{H}_{2} \mathrm{O}$ atau $\mathrm{RH}^{\cdot}+\mathrm{OH}^{-}$

$\mathrm{RH} \cdot+\mathrm{O}_{2} \rightarrow \mathrm{RH}-\mathrm{O}_{2} \cdot \rightarrow \mathrm{RH}^{+}+\mathrm{O}_{2}$.
Penambahan $\mathrm{H}_{2} \mathrm{O}_{2}$ akan menginisiasi pembentukan superoksida radikal yang akan membentuk $\mathrm{OH}^{\bullet}$ seperti pada reaksi 6-7. Reaksi $\mathrm{OH}^{\bullet}$ dengan bahan organik $(\mathrm{RH})$ akan menghasilkan carbon center radical (reaksi 8) yang akan bereaksi dengan oksigen untuk membentuk superoksida radikal yang kembali akan bereaksi dengan ozon membentuk $\mathrm{OH}^{\bullet(8)}$. Kenaikan $\mathrm{pH}$ pada proses $\mathrm{O}_{3} / \mathrm{H}_{2} \mathrm{O}_{2}$ dapat terjadi pada reaksi antara ozon secara langsung ataupun dengan $\mathrm{OH}^{\cdot}$ karena ion hidroperoksida menginisiasi dekomposisi ozon (persamaan 6-7). Namun demikian perlu dikaji penggunaan energi alternatif untuk operasional proses $\mathrm{O}_{3} / \mathrm{H}_{2} \mathrm{O}_{2}$ sehingga tidak diperlukan biaya operasional yang tinggi.

\section{KESIMPULAN}

Pada proses $\mathrm{O}_{3} / \mathrm{H}_{2} \mathrm{O}_{2}$ dengan dosis $\mathrm{H}_{2} \mathrm{O}_{2}$ yang tetap, laju aliran udara bebas mempengaruhi transfer gas pada lindi. Semakin tinggi laju aliran udara maka semakin besar konsentrasi oksigen dan ozon dalam larutan lindi. Penelitian ini juga membuktikan pengukuran KSO dapat didekati dengan pengukuran DO. Efisiensi penyisihan senyawa organik yang 
diukur sebagai COD dan $U_{254}$ juga membaik seiring dengan peningkatan laju aliran udara.

\section{PERSANTUNAN}

Penghargaan yang tinggi penulis sampaikan kepada Bapak Arief Perdana UPTD Pengelolaan Sampah TPA/TPST Regional DLH Jawa Barat atas bantuan izin dan diskusi selama proses penelitian.

\section{DAFTAR PUSTAKA}

1. Renou, S., Givaudan, J., Poulain, S. Dirassouyan, F., \& Moulin, P. (2008). Landfill leachate treatment: Review and opportunity. Journal of hazardous materials, 150(3), 468493.

2. Damanhuri, E., \& Padmi, T. (2010). Pengelolaan Sampah. Diktat Kuliah TL, 3104, 5-10.

3. Labiadh, L., Fernandes, A., Ciríaco, L., Pacheco, M. J., Gadri, A., Ammar, S., \& Lopes, A. (2016). Electrochemical treatment of concentrate from reverse osmosis of sanitary landfill leachate. Journal of Environmental Management, 181, 515-521.

4. Hereher, M. E., Al-Awadhi, T., \& Mansour, S. A. (2019). Assessment of the optimized sanitary landfill sites in Muscat, Oman. The Egyptian Journal of Remote Sensing and Space Science.

5. Bilgili, M. S., Demir, A., \& Özkaya, B. (2007). Influence of leachate recirculation on aerobic and anaerobic decomposition of solid wastes. Journal of hazardous materials, 143(1-2), 177183.

6. Cortez, S., Teixeira, P., Oliveira, R., \& Mota, M. (2011). Evaluation of Fenton and ozone-based advanced oxidation processes as mature landfill leachate pre-treatments. Journal of Environmental Management, 92(3), 749-755.

7. Gliniak, M., Lis, A., Polek, D., \& WołosiewiczGłąb, M. (2019). Advanced Oxidation Treatment of Composting Leachate of Food Solid Waste by Ozone-Hydrogen Peroxide. Journal of Ecological Engineering, 20(5).

8. Von Gunten, U. (2003). Ozonation of drinking water: Part I. Oxidation kinetics and product formation. Water research, 37(7), 1443-1467.

9. Wu, J. J., Wu, C.-C., Ma, H.-W., \& Chang, C.C. (2004). Treatment of landfill leachate by ozone-based advanced oxidation processes. Chemosphere, 54(7), 997-1003.

10. Tizaoui, C., Bouselmi, L., Mansouri, L., \& Ghrabi, A. (2007). Landfill leachate treatment with ozone and ozone/hydrogen peroxide systems. Journal of hazardous materials, 140(1-2), 316-324.

11.DLH. (2020). Status Lingkungan Hidup Provinsi Jawa Barat. Bandung: Dinas Lingkungan Hidup Provinsi Jawa Barat.

12. Gelardiansyah, S. (2015). Kelarutan Ozon pada Proses Ozonisasi Konvensional dan Advanced Oxidation Process $\left(\mathrm{O}_{3} / \mathrm{H}_{2} \mathrm{O}_{2}\right)$ pada Lindi Effluent Pengolahan. REKA LINGKUNGAN, 3(2).

13.APHA. (2005). Standard methods for the examination of water and wastewater. American Public Health Association (APHA): Washington, DC, USA.

14. USEPA, J. (1999). Alternative disinfectants and oxidants guidance manual. United States Environmental Protection Agency (USEPA).

15.Zhou, H., \& Smith, D. W. (2000). Ozone mass transfer in water and wastewater treatment: experimental observations using a 2D laser particle dynamics analyzer. Water research, 34(3), 909-921.

16. Karamah, E. F., Bismo, S., Annasari, L., \& Purwanto, W. W. (2010). Mass transfer study on micro-bubbles ozonation in a bubble column. International Journal of Chemical Engineering Research, 2, 243-252.

17. Acero, J. L., \& Gunten, U. v. (2000). Influence of carbonate on the ozone/hydrogen peroxide based advanced oxidation process for drinking water treatment.

18. Beltran, F. J. (2003). Ozone reaction kinetics for water and wastewater systems: CRC Press.

19. Sawyer, C. N., \& McCarty, P. L. (1978). Chemistry for environmental engineers. New York. Mc Graw-Hill Book Company.

20.Sururi, M. R., Roosmini, D., \& Notodarmojo, S. (2018). Chromophoric and liability quantification of organic matters in the polluted rivers of Bandung watershed, Indonesia. Paper presented at the MATEC Web of Conferences.

21.Zhang, Y., Yin, Y., Feng, L., Zhu, G., Shi, Z., Liu, X., \& Zhang, Y. (2011). Characterizing chromophoric dissolved organic matter in Lake Tianmuhu and its catchment basin using excitation-emission matrix fluorescence and parallel factor analysis. Water research, 45(16), 5110-5122.

22. Sotelo, J., Beltran, F., Benitez, F., \& BeltranHeredia, J. (1989). Henry's law constant for the ozone-water system. Water research, 23(10), 1239-1246. 
23. Reynolds, T. D., \& Richards, P. A. C. (1995). Unit operations and processes in environmental engineering: PWS Publishing Company.

24. Rezagama, A. (2012). Studi Ozonisasi Senyawa Organik Air Lindi Tempat Pemrosesan Akhir Sarimukti. Teknik, 34(2), 82-87.

25. Staehelin, J., Buehler, R., \& Hoigné, J. (1984). Ozone decomposition in water studied by pulse radiolysis. 2. Hydroxyl and hydrogen tetroxide $\left(\mathrm{HO}_{4}\right)$ as chain intermediates. The Journal of Physical Chemistry, 88(24), 59996004.

26. Frimmel, F.H. (2005), Aquatic humic substances. Biopolymers Online. Willey Online Library
27. Sururi, M. R., Siti, S. A., \& Safria, O. P. (2016). Leachate Treatment Using Advanced Oxidation Process with Zeolite as a Catalyst. IPCB 2016, 139.

28. Chen, W., Luo, Y., Ran, G., \& Li, Q. (2019). An investigation of refractory organics in membrane bioreactor effluent following the treatment of landfill leachate by the $\mathrm{O}_{3} / \mathrm{H}_{2} \mathrm{O}_{2}$ and MW/PS processes. Waste Management, 97, 1-9.

29. Glaze, W. H., Kang, J.-W., \& Chapin, D. H. (1987). The chemistry of water treatment processes involving ozone, hydrogen peroxide and ultraviolet radiation. 